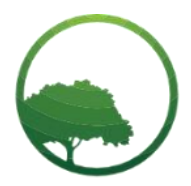

Research in Business \& Social Science

IJRBS VOL 10 NO 5 ISSN: 2147-4478

\title{
The meaning of capital of Batobo farmer groups
}

\author{
(D) Mira Gusti Ramailis (a) (iD Iwan Triyuwono ${ }^{(b)}$ (iD) Aji Dedi Mulawarman ${ }^{(c)}$ \\ ${ }^{(a)}$ Accounting Department, Faculty of Economics and Business, Brawijaya University, Jl. MT Haryono 165, Malang, Indoenesia \\ (b) Professor, Accounting Department, Faculty of Economics and Business, Brawijaya University, Jl. MT Haryono 165, Malang, Indone sia \\ ${ }^{(b)}$ Lecturer, Accounting Department, Faculty of Economics and Business, Brawijaya University, Jl. MT Haryono 165, Malang, Indonesia
}

\author{
ARTICLE INFO \\ Article history: \\ Received 08 July 2021 \\ Accepted 30 July 2021 \\ Keywords: \\ Capital, Transcedental \\ Phenomenology, Batobo \\ JEL Classification: \\ B55, L21, M41
}

Received in rev. form 29 July 2021

\begin{abstract}
A B S T R A C T
The purpose of this research was to reveal and comprehend the meaning of capital in Batobo tradition. Batobo is a traditional farmer organization, in agriculture part of the Malay society. It has been doing and agreed together and taken the turn each the fields of their members that have been agreed by them. The place has exactly been in Riau province, Kuantan district Singingi Village Kunik. Establish the enthusiastic of solidarity, family, and build up the human relationship which can be useful for many people. This Capital significance research in batobo tradition does not focus in the significance only but the capital is also useful for the society. The contribution of this research is to present regional social accounting, namely accounting that is based on social norms that care about society and the environment, and then can maintain and introduce batobo culture by embracing the nephews (millennial society) who are present in the era of medernization by not eliminating the traditional values of batobo.In research resulted in three types of capital used in the namely social capital, economic capital, and spiritual capital.This research uses interpretive paradigm with methodology phenomenology. This research concluded that there are six significances of capital from the member batobo, they are mutual cooperation, friendship, cooperative, responsibility, donation and worship.

(C) 2021 by the authors. Licensee SSBFNET, Istanbul, Turkey. This article is an open access article distributed under the terms and conditions of the Creative Commons Attribution (CC BY) license (http://creativecommons.org/licenses/by/4.0/).
\end{abstract}

\section{Introduction}

Capital has a general meaning to be understood in the meaning of material economic ownership in daily life. The capital is only determined in small meaning, referring to the items such as money, things and other property. The asset economic ownership presents an important role in the society. However, the capital is not obtained easily, but it is the result of hard working, history accumulation and dominates in a certain area. The capital is intervening to create the society whether as individually or as public.

As a part of sociality, accounting has mutual influence interaction with social public environment so that it has apart in the society (Hines 1988, Morgan 1988, Triyuwono, 2012). The society has complex characteristic social environment differently so that it's possible for the society to have knowledge and different point of view of the object which is included to understand of accountancy concept (Ahmed, 1994). Suppose that using different ways such as in business perspective, social and culture then it will produce different understanding and meaning of the object. The organization is in sociology area so that accountancy is applied by using more strategies sociology theory because it is able to relate two aspects of accountancy with society behavior and organization (Triyuwono, Mulawarman, Dzamhuri, \& Darsono, 2016).

The concept of capital that is explained by Bourdieu states that understanding of economy has reduced the meaning of capital to create confused understanding. on the other hand as opposed to non-positivists, capital is worker's accumulation when allocated individually or in groups will produce a social energy in people life. The capital always leads to an economy which is measured by the money. According to Bourdieu (Jenkins, 2004) stated that Bourdiue distinguishes capital into four categories namely economic capital, social capital, cultural capital, and symbolic capital. Mahar et.al (2005) explained that the concept developed by Bourdieu, will never leave the main capital initiated by Marx.

* Corresponding author. ORCID ID: 0000-0002-3176-2054

(C) 2021 by the authors. Hosting by SSBFNET. Peer review under responsibility of Center for Strategic Studies in Business and Finance. https://doi.org/10.20525/ijrbs.v10i5.1313 
Economy capital is one of the most influential capitals which are asset such as money, property and other wealth. Social capital, there is relationship between relation who creates social networks in people's life. Cultural capital can be converted such as prestige and education. Symbolic capital is a capital which is not created, it is unbelievable of mind but it can be converted to be the third other part. Meanwhile, in this situation the modal has different perception and known as legimate one (Bourdiue dalam (Mahar, Richard, $\&$ Chris, 2009). The title of the book The Forms of Capital, Bourdieu explained that the meaning of capital is not only understood as lack of knowledge as economy asset which referring to the money, property and wealth.

The study regarding capital meaning in batobo tradition needs to be revealed due to capital is not only known as economy (asset) but also their benefit in the society. Result of this research can be used as information and change the awareness that meaning of the capital in accounting practical is not only known as technique on capitalism; however this significance is based on the value of ritual, culture and tradition itself which appears the tradition social value. The purpose of the end of this research produces regional social accounting is based on social norm. Due to human being in world as Khalifatullah Fil Ardl it means that human as servant of Allah who is trusted to prosper the earth (Triyuwono, 2016).

Hopefully the result of this research can be useful to get the knowledge in accounting part which proves the capital is not interpreted as economy (asset); the capital can be different meaning from the other point of view. This research is able to increase the role of people to continue the batobo tradition and become social humane to work and cooperate together. Hopefully the policy maker can consider this research so that batobo tradition is long lasting and keep the tradition continuously.

\section{Literature Review}

\section{Theoretical and Conceptual Background}

\section{The Capital}

Of the many expressions of capital in everyday life, the first thing comes to a person's mind is refering to material economic things such as money, goods and other material wealth. Capital is always with the economic theory intiated by Karlx Mark which refers to the definition of economic material. With the concept of asset-lialibilty = capital. This means that capital is the company's residual righ after deducting all liabilities (IAI, 2007). Furthermore, in the statement of Financial Accounting Standars (PSAK 21) that capital is a right owned by a company, namely the difference between existing assets and liabilities and is not a measure of the selling value of the company.

According to the Big Indonesian Dictionary (KBBI) the definition of capital is money that is used as the main principal for trading, property (money, goods) can produce something that can increase wealth an so on. Referring to the Big indonesian Language Dictionary (KBBI) the notion second, capital is used by a person or several people to control the economic sector. With two combinations of meanings, it can be interpeted that capital is always discussed in the economic realm in society. Capital is goods produces by nature or humans to help the production process of other goods needed by humans with the aim of making a profit (Riyanto, 20016) Furthermore, Brigham and Houston (2006) state that economic capital ia a sum of money of material goods owned by a company and various activities aimed at making a profit.

Bourdieu (1983) distinguishes capital into four types of capital. In the presentation (Jenkins, 2004:125) it is stated that capital consist of economic capital, social capital, cultural capital, an dsymbolic capital. Among these four capitals, economic capital and cultural capital are the main determinants of social situation holders. Capital which is always understood as ownership of economic capital is a significant reduction. Bourdieu does not clearly define the notion of capital in this writtings. However, it implies an understanding that capital is always assicates with its use for certain purposes. Oriented towards.in one of Bourdieu writings (1990:112-121) entitled "symbolic capital". Contained in the book The Logic of Practice, there is an understanding that capital is used for something directed at maximizing material and symbolic profit.

\section{The Capital Modern Accounting is Kapitalism}

From some of the definiton described above can refer to the thought of capitalism, why is it called capitalism? Capitalism is the reductio of the universality of change into a mercantile exchange, which is objectively and subjectively oriented towards profit maximization, such as economic self interest (Mulawarman, 2011:45). In economic theory which emphasize the definiton of economy in practice which historically is the idea of capitalism (Mahar, et.al 2005). The philosophycal foundation of modern conventional accounting is a representation of the capitalistic, secular, and liberal western wordlview which is dominated by profit interest (Gambling and Karim, 1997 ; Baydoun and Willet, 1994 ; Triyuwono, 2006 ; Sulaiman, 2011 ; and Mulawraman 2006a).

It is known that the capital in this thingking is based on money and material that provides profit and is profit- oriented. This is what will then have an impact on self interest, greed, and opportunistic when throwing themselves in business organizations (Mulawarman, 2011:45). One form of capitalism is the loss of interest (disinterested) (Bourdieu, 1983). And in modern accountig, the main value is egositic and the second value is materialistic (Triyowono, 2006b:107). Both of these traits get justification from the values of utilitariansm. Utilitariansm basically has the assumption that the good or bad value of an action ismeasured by the presence or absence of utility (material) resulting from an action. As long the action produces utility, so long as an action is said to be good regardless of 
how the process is carried out. Even though it does not rule out the possibility that the process carried out is actually contary to the ethical values that apply and society (Triyuwono, 2006).

This reality can at least be evidence that the emergence of deviations in capital is built on medern accounting (western science). However, science and truth should also not impose ontological restrictions on metaphysical things that have been carried out by western or modern science that have made it materialistic (Triyuwono, 2005:101). At least it becomes a benchmark for us that capital in modern accounting is full of greed.

The view as Muslim in understanding the context of the orientation of capital that ends in profit for self interest is not justified, where capital is very small with a very large profit orientation. Capital in the Qur'an are described in Qs. Ali Imran:14 :

" made beutiful in the eyes of man the love of what he wants, namely women, children, welath of many kinds of gold, silver, horses of choice, livestosk, and fileds. That is the pleasure of living in this world and with Allah is a good place to return (Heaven)".

From the verse explained that love for material things (woman, children, property) is a basic human nature because it is related to needs, but one should not follow the desires of the world to fulfill the needs of the world so as to forget the afterlie, property is a human need. So the treasure here is capital for us to seek profit but it should not be excessive which causes neglect of his orders. So make it as capital for the welfare of the hereafter.

The position of humans as social beings is Islam recognize the existence of differentiation and even social polarization, in the Qur'an sees the phenomenology of social inequality refered to as Sunatullah, as natural law and empirical reality destined for mankin. The empirical social reality filled with the pheneomenon of differentation and polarization by the Qur'an is seen as a real arena of worldly life where every Muslim will fight for his deals of social justice. His involvement in the struggle will determine his quality as khalifatullah fil'ard (Kuntowijoyo, 2017:327).

\section{Research and Methodology}

Research used a qualitative method by using interpretive paradigm and a phenomenological approach. The qualitative methods are also called as constructivist or natural approaches (Sudarma, 2010). This research is included in apart of interpretive paradigm as the purpose of this research in exploring the understanding of informants. This statement has agreed with the explanation (Burrel \& Morgan, 1994) about interpretive paradigm stated that human as free life, independent being, and able to create social worlds, ideas, concept and theories. Therefore at the end of this research purpose is to understand and explore the meaning of capital from the traditional batobo value.

Using phenomenology as an approach is based on the purpose of this research, which is focus on the awareness and understanding of informants and experiences (Mulawarman, 2010). It aims to have an understanding to social reality of the informants (perspective) in general which of course that is not determined earlier but is obtained after analyzing the reality which is the focus of this research. Phenomenology is an appropriate analytical tools to reveal awareness due to experience because of the main goal of phenomenology which to learn how the phenomena is experienced in consciousness, ideas and action such as how the phenomena are valued and accepted aesthetically (Kuswarno, 2009). The research location was conducted in Padang Kunik Village, Pangean distrct, Kuantan Singingi Regency Riau Province. Padang Kunik Village is one of the active villages in carrying out and maintaining the batobo tradition and respects the traditional cultural values across generations.

Phenomenology comes from the Greek word Phainomai which means to view. Phenomena are facts that are realized into human understanding. Phenomenon is a consciousness that is not visible as real object; phenomenology describes human experiences related to objects (Kuswarno, 2009). According to The Oxford English Dictionary, phenomenology is 1). The science of phenomena as district from that of the nature of being, 2). An approach that concentrates on the study of consciousness and the objects of direct experience. Phenomenology studies the awareness of phenomena and objects of direct experience (Oxford, 1989).

According to Husserl, with phenomenology we can learn some experiences from point of view of people who experience them directly, as if experiencing them themselves. All of that comes from how a person interprets objects in his life experience (Kuswarno, 2009). Husserl stated that through his writing entitled logical investigations; relate two of psychology, namely descriptive psychology and logic. Husserl also used the process of conscious awareness (real objects) with noesis while noema for awareness (objects in perception). Husserl also used epoche to prevent misunderstanding. By using epoche we are able override the judgments, refraction and initial considerations that we have in an object (Kuswarno, 2009).

This study uses transcendental phenomenology. Therefore transcendental phenomenology can describe the overall discovery of the significance and nature of experience, and the difference between fact and essence so that it can distinguish between real and unreal (Kuswarno, 2009). During the data collection in the field, it helped the researcher to examine the significance and connected with their mind, so that the researcher can understand the significance and essence of self-intuition and suspend a natural attitude with the intention of understanding it. It will better way and directly to describe our experiences naturally without questioning the origins of psychology and the causal explanations that scientists, historians and sociologists can provide (Merleu \& Bertens, 1987). 
In terms of methodology, Transcendental Phenomenology also has four conceptual components as the unit of analysis, namely: 1). Intentionality (intentional), 2). Noema and noesis, 3). Intuition and 4). Intersubjectivity. These four units of analysis are one of all that are described and merged in the data analysis process through bracketing, horizonalizing, and horizon (Moustakas, 1994). Based on (Moustakas, 1994) stated that one the main characteristics phenomenology is exploring in groups of individuals who have experienced the phenomenon. In this research, there were five (5) batobo members each of the members might have the different interpretation regarding capital. The next characteristic of phenomenology is a discussing of philosophical about the basic ideas which involved in phenomenology, namely the life experiences of individuals and how individuals have subjective experiences of phenomena and objective experiences of the same thing with other people.

The main data of this research is collected by conducting interviews with informants and observations. Interviews and data collection were carried out by real practical in the field which visited the informant's place as well as visiting the research site. Researchers recorded the results of the interviews and accompanied by photo evidence for transcription and analysis.

Table 1: List of Informants

\begin{tabular}{lll}
\hline $\mathbf{N o}$ & Name & Information \\
\hline $\mathbf{1}$ & Ms. OID & Head of Batobo group \\
\hline $\mathbf{2}$ & Mr. DBS & Traditional leader (Tobo member) \\
\hline $\mathbf{3}$ & Mr. DTM & Tuo Banjar (Tobo member) \\
\hline $\mathbf{4}$ & Mr. FTY & Kades Padang Kunik (Tobo member) \\
\hline $\mathbf{5}$ & Mr. HAL & Religious leader (Tobo member) \\
\hline
\end{tabular}

The informants of this research consists of head of the group, head of the village, Tuo Banjar (Spiritual expert), Malin (Religious leader), Ninik Mamak (Traditional leader) and the citizens Padang kunik village. The researcher chose these members due to they had experienced in batobo event directly. These are the stages of transcendental phenomenology research as per this below:

Data Analysis

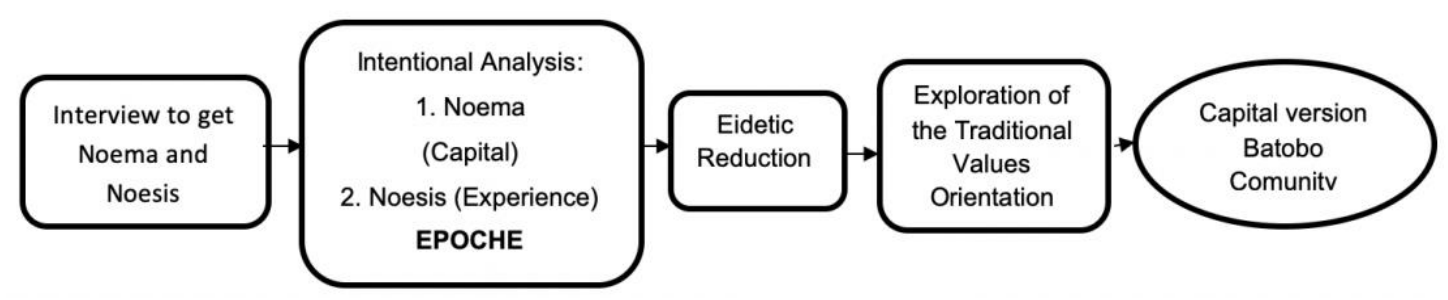

Figure 1: Data Analysis; Source: Fenomenology Transcedental Husserl

\section{Result and Discussion}

The results of this research is findings some the essence of significance based on the experience of batobo farmers. The experience related to the value system of the traditional way of life the Kuantan Malay community, in their daily activities, which include religion, customs, and Islam.

\section{Batobo Cultural Tradition}

The history of the development of batobo came and developed in Rantau Kuantan around the 70s. Initially batobo had been done only by women because men did not live in the village so that agricultural affairs were left entirely to women. Batobo is divided into, female tobo whose members are female, tobo Bujang which consists of men, then develops again with batobo Bujang Gadih, whose members consist of both male and female (Alfindo, 2016).

The characteristic of this organization is built up with aim carrying out social activities such as celebrations, arts and cultural traditions, and opening up agricultural land. Sources of funds were given by group members, communities and donors. The society goal is more prioritizes rather than personal goal. These three characteristics of this batobo are the main asset in the organization. There was an agreement that should be committed by every member. The agreement is not written, only in the form of an 
announcement that is conveyed to all members of tobo. This agreement helped them be easier for organizations to develop themselves to achieve their goals. As stated as expressed by Mr. DBS:

“... Many people had difficult lives over the past of year. They only had gardening and going to the fields. It took a long time. However batobo can solve their problem by working together in turns. They will take turn one by one each member and so on".

Batobo has differences with farmer groups, the differences can be detailed from: 1). the way they measure the area of agricultural land using their own version of the traditional calculation. Then it will be converted into modern calculations to produce a proportional amount, 2). Showing the existence of the batobo group, they play traditional musical instruments, to entertain the working environment in the rice fields, 3). The activity of batobo is called parari, which look likes social gathering which is done by all group members in turn.

There is a series of traditional Malimauan ritual processes, which means to purify in the batobo process. As mentioned by Mr. DTM:

"As Muslims we should be praying and thanks to the god before opening the new farmer land so that our land will be bless by the god and keep peaceful season environment".

Based on the description above, the informant understands that batobo is the way of working together in groups' traditional farmer which is still maintaining their traditional values. There is a good manner and attitude in batobo society from the group members. In their daily life, they really high respect the norm and the value of their villages' policy rules and Malay culture, which are based on three systems of traditional value orientation, namely resam, tradition, and Islam (tradition based on syarak, syarak refer to Kitabullah) (Hamidy, 2003). As for one of the values of the traditional orientation, namely:

"There live as low profile; the debt is not only outlook problem but also as moral problem. Therefore they believed that bless of their property is more important rather than the amount of it. Honesty is the ultimate display of self-worth. Family relationship is part of togetherness. Language is a symbol of character. The balance of inner and outer is the crown in the crown of life. Disputes are avoided as much as possible".

\section{The Meaning of Capital Version of the Batobo Farmer Group and Traditional Social Values}

First, understanding the meaning of modal version of batobo members is collaboration. It is a reflection of the social aspect. The explanation of understanding the meaning of modal in the batobo tradition leads researchers to understand the experiences expressed by Mr. DTM, a spiritual expert stated that:

"The important thing for me regarding this capital in batobo is collaborative, groups and cooperates together honest and sincerely, then help another duty of the other group until get it done. The spirit of solidarity will be strong while giving helps in batobo".

As a tuo banjar (spiritual expert) Mr.DTM is trusted until now. The culture of batobo is not only applied to agricultural land but also it is also applied in the social life of the community. As this statement bellows:

"Collaborative are not only for group members, but it also involved the people to be participated in thanks giving events (olek padang)".

The same statement is received from (Malin) such as the expression stated below:

"The solidarity energy will happen with collaborative behavior, whatever we have whether in energy, and property, we donate to other people need it so that it will be useful and become a reward in the worship.

Collaborative is also used to collect the funds of unity which are used to finish the tobo. The event will be held and planned in earlier. At the same time they will inform and gather the member of society to keep the relationship. This is expressed by the following below:

"It's not easy to gather the people. Moreover, there are some residents who stayed out of the city and they do not stay in the village anymore. So the preparations should be ready from the long day before. Some of the people must attend the event such as community leaders, village heads, tuo banjar (spiritual experts), malin (religious leaders).

Based on the description above, it can be understood that the members of batobo are aware that mutual cooperation is a very influential capital in the batobo tradition. The gathering of all members of the community in completing a job is a traditional view for the community which reflects the attitude of mutual cooperation between each other with the same guidelines (Koencaraningrat, 1980). Mutual cooperation does not only help physically but also regarding costing. They are willing to donate as much as they have as the teamwork in tooband build up strong relationship (Sariubang, 2014, Tumirin \& Abdurahim, 2015).

Second, according to batobo members understanding the meaning of the batobo is Keep in touch the relationship. It is a reflection of the social aspect. This is what distinguishes traditional and modern farming systems. In each activity, the batobo group is more caring and empathetic towards members and the community. This is as expressed by the Mr.FTY (Village Head) as the following:

"batobo tradition is still strong in Padang Kunik village. Their farming system is known as traditional. There is still a tradition of thanksiving as gratitude and maintaining relationship in our village". 
For more detail revealed as in Mr. FTY, as stated below:

"This people need and dependence each other. For example: there is one resident who is sick, they must help, visit, care the situation, and stay in touch".

The understanding of FTY carried out of a responsibility as a Village Head who cares for his residents. Always interactive, good communication will create trust between group members, and show that there is a sense of caring for other members. Furthermore, Mr.FTY reaffirmed his explanation:

"The friendship should keep maintain well, it will be apathetic when we do not keep it, still keep going to maintain good relationship with the groups. We are lucky staying in the village, tolerate each other and keep maintain. Don't be a selfish person if we can't help with material things, be open just help as much as we can".

In another place Mr. DBS revealed the same point of view, such as this following below:

"There is a synergy value of the batobo, which is forms the value of interaction between group members and the community, potang den goluoghosan, den ado ubeknyo (yesterday I had a shiver and fever) then the other member will answer that (I have the medicine), well there is an interaction here in sharing about their life problem".

In continuously his opinion:

The best part in batobo tradition is there was a target that they should achieve and due date to motivate their members. Here is for further DBS stated that:

"If make it possible we can finish it before dzuhur time praying so that we can have lunch together where the food is wrapped in banana leaves and traditional utensils".

Even though batobo tradition had started disappear with generation development, however the young people have their own creative to develop batobo. They create their own community and groups.

"Over the past year... the meeting hall building in Taluk City was called the batobo building, unfortunately today the building is functioned anymore. I hope that with this batobo can give some efficient values whether in quality or quantity".

Mr. DBS is in another explanation as following below:

"batobo should be doing by the human so that it has some values as humanity, it's not proper when it is done by when batobo is being done by the tool and machines. It will be different when it's done by individually the result is only "one piece" (1) "the result will be "three pieces (3)".

In another in their explanation Mr. DBS stated that:

"I have ever written a book entitled raja buncit kedekut where the summary of the book contains many values and norms that exist in society. It turns out that traditional values are able to differentiate and become a solution in the modern world. Basically, we have to be friendly; we might not be arrogant with that power, position, wealth, all of that is only a temporary from the God. We cannot underestimate other people".

The experience of DBS has created an understanding that the meaning of capital is not only in terms of material, money, and costs incurred by the group leader, but in another view the meaning of capital in batobo tradition is keep maintain the relationship (friendship). Based on the description above, it can be understood that friendship can strengthen good relations between group members and the community. Even though it began to be eroded with the times, it can still survive and adapt to the current generation. Where millennial young people have their own way to develop the batobo itself, namely by creating communities, groups and so on.

Third, understanding the meaning of the batobo member's modal meaning is Cooperation. It is a reflection of the social aspect. As social human beings, we have to help each other, without exception, cooperation helps the work easier and can be completed quickly. As stated proverb shows that "bagaikan aur dengan tebing". The meaning of describes how closely the supporting of the reed is with the cliff. Reed requires a cliff to grow, and the cliff is safe (not collapsed) because there is reed. That's why this expression is used to teach lessons of life to be beautiful, mutual need and giving benefit each other. Understanding the meaning of capital is assembling which can be observed in interviews with informants who are also related to the batobo tradition. This is as expressed by the following Mr.INS:

"As we know that in batobo something that concerns the nationality will discuss and complete it collectively down to the rice fields not individually".

The understanding of INS is inspired of a Head of Culture and Tourism. At the time he served as a cultural observer of Kuantan Singingi Regency.

Mr. INS revealed that: 
"We are always invited when there is a batobo celebration, especially in the event of thanksgiving (olek Padang). Well... it's impossible to held the event when we were doing by ourselves. Definitely we need cooperation and collaboration to success the event".

For further story Mr.INS tells the experiences:

"Nowadays, life has been changes a lot. Of course, we hope we don't forget with our customs and culture, cooperation, and working together. Long time ago the people worked sincerity, compared to current situation there has changed fatly and everything is based on the money".

Mr. DFM has a similar understanding of Mr. INF as the following expression:

"Yes, that's right ...In the batobo you have to work together. 12345 (pointing to the researcher and to one of the informants) For example: when we have a project. It will take seven (7) days to complete as individually working; if we work together the results will be completed faster".

The understanding of Mr. DFM carried of its involvement in the Malay Customary Institution. Mr. DFM said that cooperation is an attitude of humility and unites differences between members of the batobo group. There have been mutual respect in order to build happy, safety and enjoyable to reach the common goals.

The conclusion from the description above is based on the experience and understanding of the informants that togetherness is the main reason in the batobo tradition. Having low profile attitude of the each individual to respect the difference ideas and opinions to create the feeling safety and comfort to achieve a goal. Family relationship is one part of cooperation which stated as wealth, energy, and thoughts. We can help how much our effort in any kinds of help to the member.

Fourth, understanding about the meaning of capital based on batobo member's version is a responsibility. It is a reflection of the social aspect; we carry out our work as are required to be full of responsibility. We have the responsibilities to the God almighty, the state, the community, and oneself.

Each individual has different responsibilities. So it is important for the leader and group members to always be responsible for all their duties. This is as expressed by the following Mrs. OID:

"Being a group leader is not just about setting the form of an agreement. I am also being responsible as a housewife. I have lived this for generations. At the beginning my parents (Mak Dijjah) now I replace her. The responsibility must be carried out; we have been chosen, so that we must trust our families, members, groups and society".

His understanding in interpretation the capital in the batobo tradition which creates a responsibility that comes from this OID being a group leader. Being responsible is a mandate for him personally, to group members and society. This is an attitude that everyone should emulate. Always be open and transparent, and be fair to others. So it is important for the leader and group members to always be responsible for all their duties.

For further detailed Mrs. OID stated that:

"At the beginning, the seeds are given by the government and were entrusted to me. Then I distributed the seeds to each member. And it's not only for the members who are distributed because here the people can't afford it. I feel sorry that even though it is not intended for the general public and society, but I share it with people who deserve to be helped. Well... I share even though I get both a little. We have to be open here".

Based on the description above, we can conclude that as the group leader, Mrs. OID is responsible not only to group members but also to the community and the surrounding environment. OID proved that as a group leader, you should be transparent and be open to your group members.

The responsibility is expressed by Mrs. OID as this following below:

"batobo has been around since 1990 since then; I have not been married until now. So if you ask about my experience, of course I have a lot, like the proverb stated that "tasting sour and salt".

Mrs. OID revealed the capital in the batobo tradition as responsibility. Responsible and always be open transparent for self, family, group members and society.

The Mrs. OID understanding as the same as BT understanding showed that:

"The leader of batobo group was a woman over the year because at the time the man should go to another place to find the job. So that the women will go to fields and doing some works. Traditional values in batobo still exist. If it can be maintained, we do not deny that there is cultural acculturation".

Continually to express his idea: 
"Let it be batobo with what already stated. They measure in their own way and version. It will not to be forced to use the meters, like modern agricultural measurements. Just let it be".

Understanding Mr. BT is created from his experience as a humanist and has been involved in tobo tradition directly.

The conclusion from the above description can be concluded that the meaning of capital in the batobo tradition is responsibility. The responsibility of the group leader to group members and the community and having great attitude and transparent and being fair to others.

Fifth, understanding the meaning of the batobo member's version of capital is Donations. It is a reflection of the economic aspect. In this context, economic capital is related to the costs incurred during the batobo process. Costs incurred for the purchase of sacrificial animals. The funds that they have been collected will be giving also for those people who need help, support and charity.

There was aimed at the common interest and benefit the community activities. Of course the process of the event is of material value. This is evident we can see when buying sacrificial animals and the price is expensive. However society did not see how expensive it was because it was used for the common good (celebration Idul Adha) and it gave benefited to many people. Donations are also given to people in need, such as feasts (party), and people who can't afford for it. Donations are given sincerely on the basis of a sense of humanity so that the person who received they will be feeling happy and blessing. As we know that, basically in studying about accounting is always related with the value due to the process of created need the humanity and it's very important. As long as humans are involved in it, as long as human creations will always be value laden (Triyuwono, 2006). There are two account in modern accounting has two values, namely egoistic and materialistic. Both of these values involve money and profit, both of which are justified by utilitarian values (Triyuwono 2006, 107)

Another aspect of economic capital that is formed from the meaning of capital in the traditional batobo event is at harvest time. The harvest is not for sale to the market but it will be used in daily life of the batobo members. The harvest is also used for the use for the celebration days such as Ramadan and Eid Idul Fitri and as a stock for the next one year. Then the next harvest will be donated to the community holding a feast (party). This is the same line with what the OID stated below:

"The community will contribute to complete the tobo's activity before the thanks giving event. They will not set the fee, it's free. Then all the funds have been collected to buy sacrificial animals, it will be cooked by the committee, and distributed to others".

The next continuously:

"The tradition of the village is supporting others; if there are people who are less able we can help to donate the harvest to people who are holding the events. People's lives were difficult in the past, so the harvest was lent, later if you wanted to pay it was fine, if you didn't pay it was okay. In this village, it's like we are all family. Help each other is as mandatory.

From the statement above, the researcher can see that donations and contrubutions are made sincerely and without expexting a reward. The researcher tries to ask again, why the community members do not pay compensation if they have borrowed the haverst, Mrs OID? Event though that was the effort of the mother planting and the other members?

Furthermore, Mrs. OID said in her speech:

"We have been doing this for a long time, since munyang (the farmer) is our vilage. The harvest is lent if there is a feast, some pay for it, some don't pay it in full. Here we are all family. It has something to do with this., this s a nephew, this is a brother. But nowadays it is rarely done. Times are modern. But the harvest, sugar, coconut are still donated. In fact, people pay fpr it with money"

The next continuously Mr.DBS stated that:

"The people will support each other in the past. Nowadays everything should be measured by the money".

Based on the description above it can be concluded that understanding the meaning of capital cannot be separated from valuable (material) economic capital. However all of it does not change the understanding and meaning of a capital that is inherent and used in an organization.

Sixth, understanding the meaning of the modal version of the batobo members is Worship. It is a spiritual aspect reflection. Understanding the meaning of capital as worship in the batobo tradition leads to the highest dimension aspect. According to (Seligman 2005) that to achieve more meaningful life we have to connect ourselves with challenging things. The larger the entity to which the individual attaches himself, the more meaningful one's life is. This means that to find the meaning and purpose of life, we should have guideline to the institutionalized religion, namely the religion we believe in.

As the same line with research (Nelson, 2009) which reveals that spirituality can help a person to find the significance of his life, encourage them to always have positive thingking, encourage harmony with God, nature, society, and find peace of mind and heart. In this life, in reality, humans are not alone, that is, there is our spiritual reality in God that is inherent in humans (Triyuwono, 2006). The discovery of the modal meaning of worship in the batobo tradition started with OID. Based on the small discussion we had opinion that it was normal if he thought that way. As stated below: 
"Even the result of the harvest is only received small but it made me always to feel grateful. I feel happy and not burdened by the people here. During harvest, festivals, and people who are experiencing calamities, we always help and share with them".

Mrs. OID shows that any assistance and results received in teaching to share not only with members, but also with communities in need. Even though received only a little but we have to keep sharing and always be grateful.

Continually to express his idea:

"Here is needed our role to help the poor people, sincere because of Allah Subbanahahu wa 'tala".

Giving charity sincerely and sincerely because of Allah Subbahanahu Wa ta'ala. We do not ask and expect the rewards from humans but only hope for the pleasure of Allah Subbahanahu Wa ta'ala. This is a part of worship. Understanding

Mrs. OID is in line with understanding Mr. HAL. As expressed below:

"While thanksgiving event was happening, there was a series of rituals, traditional culture, and religion. If the customary law is read out, it is called descending rajo adat (advice or advice). The information is about the rules of the religion. Next is the reading of the prayer that is followed together. Like the prayer of Talaq bala, tahil, and dzikir together. At the end of the event closing let's praying together".

The understanding as the same line as Mr. INS showed that below:

"batobo is not a belief, but there is a ritual value there, they believe that there is a suitable and lucky day to go down to the rice fields. Then the rice seeds that have been spelled out, there are also mystical elements but we as adherents of Islam; of course we don't believe it. For example in modern situation we still believe in shamans for treatment, if you believe, yes...we will get discovery, actually you is discovery through Allah Subbahanahu Wa ta'ala because believing in the shaman is disgrace. So how we respond to things that mix rituals it depends on us".

Based on the description above, it can be concluded that understanding the meaning of capital can be deliver as worship. We will always praying at any time to Allah Subbahanahu Wa ta'ala. It's not only followed to tradition rules but we should submit to religious orders. Always be grateful, pray dzikir and pray to do his orders and stay away from his prohibitions. It is an act of worship to Allah Subbahanahu Wa ta'ala. Good attitude, sincere to fellow human beings and not expecting material rewards, is a spiritual value by aligning intentions and beliefs that working together in a group full of responsibility is a value of worship.

\section{Meaning of Capital Version Batobo Community}

Various discussions and results obtained regarding the meaning of capital of batobo farmer groups by member's batobo that do not have material elements described in the following table.

Table 2: Practioners Meaning of Capital

\begin{tabular}{|c|c|c|c|c|}
\hline The Meaning & Noema & Noesis & $\begin{array}{l}\text { Intentional } \\
\text { Analysis }\end{array}$ & Eidetic Reduction \\
\hline $\begin{array}{l}\text { Mutual } \\
\text { Cooperation }\end{array}$ & $\begin{array}{l}\text { "The important thing for } \\
\text { me regarding this capital } \\
\text { in batobo is } \\
\text { collaborative, groups } \\
\text { and cooperates together } \\
\text { honest and sincerely, } \\
\text { then help another duty of } \\
\text { the other group until get } \\
\text { it done. The spirit of } \\
\text { solidarity will be strong } \\
\text { while giving helps in } \\
\text { batobo". }\end{array}$ & $\begin{array}{l}\text { "Collaborative are not } \\
\text { only for group members, } \\
\text { but it also involved the } \\
\text { people to be participated } \\
\text { in thanks giving events } \\
\text { (olek padang)". }\end{array}$ & $\begin{array}{l}\text { "The solidarity } \\
\text { energy will happen } \\
\text { with collaborative } \\
\text { behavior, whatever } \\
\text { we have whether in } \\
\text { energy, and } \\
\text { property, we donate } \\
\text { to other people need } \\
\text { it so that it will be } \\
\text { useful and become a } \\
\text { reward in the } \\
\text { worship. }\end{array}$ & $\begin{array}{l}\text { "It's not easy to gather } \\
\text { the people. Moreover, } \\
\text { there are some residents } \\
\text { who stayed out of the city } \\
\text { and they do not stay in the } \\
\text { village anymore. So the } \\
\text { preparations should be } \\
\text { ready from the long day } \\
\text { before. Some of the people } \\
\text { must attend the event such } \\
\text { as community leaders, } \\
\text { village heads,tuo banjar } \\
\text { (spiritual experts), malin } \\
\text { (religious leaders). }\end{array}$ \\
\hline
\end{tabular}




\begin{tabular}{|c|c|c|c|c|}
\hline Friendship & $\begin{array}{l}\text { "batobo tradition is still } \\
\text { strong in Padang Kunik } \\
\text { village. Their farming } \\
\text { system is known as } \\
\text { traditional. There is still } \\
\text { a tradition of thanks } \\
\text { giving as gratitude and } \\
\text { maintaining relationship } \\
\text { in our village". }\end{array}$ & $\begin{array}{l}\text { "This people need and } \\
\text { dependence each other. } \\
\text { For example: there is one } \\
\text { resident who is sick, they } \\
\text { must help, visit, care the } \\
\text { situation, and stay in } \\
\text { touch". }\end{array}$ & $\begin{array}{l}\text { "The friendship } \\
\text { should keep } \\
\text { maintain well, it will } \\
\text { be apathetic when } \\
\text { we do not keep it, } \\
\text { still keep going to } \\
\text { maintain good } \\
\text { relationship with the } \\
\text { groups. }\end{array}$ & $\begin{array}{l}\text { "batobo should be doing } \\
\text { by the human so that it has } \\
\text { some values as humanity, } \\
\text { it's not proper when it is } \\
\text { done by when batobo is } \\
\text { being done by the tool and } \\
\text { machines. It will be } \\
\text { different when it's done by } \\
\text { individually the result is } \\
\text { only "one piece" (1) "the } \\
\text { result will be "three } \\
\text { pieces (3) }\end{array}$ \\
\hline Cooperative & $\begin{array}{l}\text { "As we know that in } \\
\text { batobo something that } \\
\text { concerns the nationality } \\
\text { will discuss and } \\
\text { complete it collectively } \\
\text { down to the rice fields } \\
\text { not individually". }\end{array}$ & $\begin{array}{l}\text { "We are always invited } \\
\text { when there is a batobo } \\
\text { celebration, especially in } \\
\text { the event of thanksgiving } \\
\text { (olek Padang). Well... it's } \\
\text { impossible to held the } \\
\text { event when we were doing } \\
\text { by ourselves. Definitely } \\
\text { we need cooperation and } \\
\text { collaboration to success } \\
\text { the event". }\end{array}$ & $\begin{array}{l}\text { "Nowadays, life has } \\
\text { been changes a lot. } \\
\text { Of course, we hope } \\
\text { we don't forget with } \\
\text { our customs and } \\
\text { culture, } \\
\text { cooperation, and } \\
\text { working together. } \\
\text { Long time ago the } \\
\text { people worked } \\
\text { sincerity, compared } \\
\text { to current situation } \\
\text { there has changed } \\
\text { fatly and everything } \\
\text { is based on the } \\
\text { money". }\end{array}$ & $\begin{array}{l}\text { "Nowadays, life has been } \\
\text { changes a lot. Of course, } \\
\text { we hope we don't forget } \\
\text { with our customs and } \\
\text { culture, cooperation, and } \\
\text { working together. Long } \\
\text { time ago the people } \\
\text { worked sincerity, } \\
\text { compared to current } \\
\text { situation there has } \\
\text { changed fatly and } \\
\text { everything is based on the } \\
\text { money". }\end{array}$ \\
\hline $\mathbf{R e}$ & $\begin{array}{l}\text { "Being a group leader is } \\
\text { not just about setting the } \\
\text { form of an agreement. I } \\
\text { am also being } \\
\text { responsible as a } \\
\text { housewife. I have lived } \\
\text { this for generations. At } \\
\text { the beginning myparents } \\
\text { (Mak Dijjah) now I } \\
\text { replace her. The } \\
\text { responsibility must be } \\
\text { carried out; we have } \\
\text { been chosen, so that we } \\
\text { must trust our families, } \\
\text { members, groups and } \\
\text { society". }\end{array}$ & $\begin{array}{l}\text { "At the beginning, the } \\
\text { seeds are given by the } \\
\text { government and were } \\
\text { entrusted to me. Then I } \\
\text { distributed the seeds to } \\
\text { each member. And it's not } \\
\text { only for the members who } \\
\text { are distributed because } \\
\text { here the people can't } \\
\text { afford it. I feel sorry that } \\
\text { even though it is not } \\
\text { intended for the general } \\
\text { public and society, but I } \\
\text { share it with people who } \\
\text { deserve to be helped. } \\
\text { Well... I share even } \\
\text { though I get both a little. } \\
\text { We have to be open } \\
\text { here". }\end{array}$ & $\begin{array}{l}\text { "batobo has been } \\
\text { around since } 1990 \\
\text { since then; I have } \\
\text { not been married } \\
\text { until now. So if you } \\
\text { ask about my } \\
\text { experience, of } \\
\text { course I have a lot, } \\
\text { like the proverb } \\
\text { stated that "tasting } \\
\text { sour and salt". }\end{array}$ & $\begin{array}{l}\text { "Let it be batobo with } \\
\text { what already stated. They } \\
\text { measure in their own way } \\
\text { and version. It will not to } \\
\text { be forced to use the } \\
\text { meters, like modern } \\
\text { agricultural } \\
\text { measurements. Just let it } \\
\text { be". }\end{array}$ \\
\hline
\end{tabular}




\begin{tabular}{|c|c|c|c|c|}
\hline Donations & $\begin{array}{l}\text { The community will } \\
\text { contribute to complete } \\
\text { the tobo's activity before } \\
\text { the thanks giving event. } \\
\text { They will not set the fee, } \\
\text { it's free. Then all the } \\
\text { funds have been } \\
\text { collected to buy } \\
\text { sacrificial animals, it } \\
\text { will be cooked by the } \\
\text { committee, and } \\
\text { distributed to others". }\end{array}$ & $\begin{array}{l}\text { "The tradition of the } \\
\text { village is supporting } \\
\text { others; if there are people } \\
\text { who are less able we can } \\
\text { help to donate the harvest } \\
\text { to people who are holding } \\
\text { the events. People's lives } \\
\text { were difficult in the past, } \\
\text { so the harvest was lent, } \\
\text { later if you wanted to pay } \\
\text { it was fine, if you didn't } \\
\text { pay it was okay. In this } \\
\text { village, it's like we are all } \\
\text { family. Help each other is } \\
\text { as mandatory. }\end{array}$ & $\begin{array}{l}\text { "We have been } \\
\text { doing this for a long } \\
\text { time, since munyang } \\
\text { (the farmer) is our } \\
\text { vilage. The harvest } \\
\text { is lent if there is a } \\
\text { feast, some pay for } \\
\text { it, some don't pay it } \\
\text { in full. Here we are } \\
\text { all family. It has } \\
\text { something to do with } \\
\text { this., this s a nephew, } \\
\text { this is a brother. But } \\
\text { nowadays it is rarely } \\
\text { done. Times are } \\
\text { modern. But the } \\
\text { harvest, sugar, } \\
\text { coconut are still } \\
\text { donated. In fact, } \\
\text { people payfpritwith } \\
\text { money" }\end{array}$ & $\begin{array}{l}\text { "The people will support } \\
\text { each other in the past. } \\
\text { Nowadays everything } \\
\text { should be measured by the } \\
\text { money". }\end{array}$ \\
\hline Worship & $\begin{array}{l}\text { "Even the result of the } \\
\text { harvest is only received } \\
\text { small but it made me } \\
\text { always to feel grateful. I } \\
\text { feel happy and not } \\
\text { burdened by the people } \\
\text { here. During harvest, } \\
\text { festivals, and people who } \\
\text { are experiencing } \\
\text { calamities, we always } \\
\text { help and share with } \\
\text { them". }\end{array}$ & $\begin{array}{l}\text { "Here is needed our role } \\
\text { to help the poor people, } \\
\text { sincere because of Allah } \\
\text { Subbanahahu wa'tala". }\end{array}$ & $\begin{array}{l}\text { "While thanksgiving } \\
\text { event was } \\
\text { happening, there } \\
\text { was a series of } \\
\text { rituals, traditional } \\
\text { culture, and } \\
\text { religion. If the } \\
\text { customary law is } \\
\text { read out, it is called } \\
\text { descending rajo adat } \\
\text { (advice or advice). } \\
\text { The information is } \\
\text { about the rules of the } \\
\text { religion. Next is the } \\
\text { reading of the prayer } \\
\text { that is followed } \\
\text { together. Like the } \\
\text { prayer of Talaq } \\
\text { bala, tahil, and } \\
\text { dzikir together. At } \\
\text { the end of the event } \\
\text { closing let's praying } \\
\text { together". }\end{array}$ & $\begin{array}{l}\text { "batobo is not a belief, } \\
\text { but there is a ritual value } \\
\text { there, they believe that } \\
\text { there is a suitable and } \\
\text { lucky day to go down to } \\
\text { the rice fields. Then the } \\
\text { rice seeds that have been } \\
\text { spelled out, there are also } \\
\text { mystical elements but we } \\
\text { as adherents of Islam; of } \\
\text { course we don't believe it. } \\
\text { For example in modern } \\
\text { situation we still believe } \\
\text { in shamans for treatment, } \\
\text { if you believe, yes...we } \\
\text { will get discovery, } \\
\text { actually you is discovery } \\
\text { through Allah } \\
\text { Subbahanahu Wa ta'ala } \\
\text { because believing in the } \\
\text { shaman is disgrace. So } \\
\text { how we respond to things } \\
\text { that mix rituals it depends } \\
\text { on us". }\end{array}$ \\
\hline
\end{tabular}

\section{Implication}

Theoretically, we can see that the results of the research found show that accounting practices are not only found from practice in the form of numbers. However it also understands about the accounting can be observed the arts and culture that exist in an area influenced by traditional values, local wisdom, customs and culture. On a practical level, this research is able to create an understanding of traditional regional social accounting. That understanding the concept of capital from an organization is not only of material value, but also socially and spiritually valued. In policymaking, this research can be a reference in understanding a concept in understanding capital in a traditional farmer organization. And The contribution of this research is to present regional social accounting, namely accounting that is based on social norms that care about society and the environment, and then can maintain and introduce batobo culture by embracing the nephews (millennial society) who are present in the era of medernization by not eliminating the traditional values of batobo. 


\section{Conclusions}

After a long the journey in this research that completed step by step and the stages in the research, the researcher realized that there was diversity in interpreting the meaning of capital in the traditional batobo agricultural tradition.

First. The meaning of the capital is an aspect of social and cultural capital which consists of: cooperation, it is a gathering of group members and the community to help each other in social life with the aim of collecting funds for the unity of tobo. Keep in touch, which can build up strong relationship and gathering between group members and the community, regardless social status. Having the same point of view to achieve common goals with strong relationship each other. They work together and sit down involving all members their action, share the ideas and giving opinion. The soul and spirit of the batobo is a strong and bounding relationship. Responsibility is a mandate and attitude that should be followed by every member of the tobo. They have to always being open and transparent and fair to others.

Second. The meaning of capital donation is contributions from group members, donors, parties and the community. The donors are giving their donations and contributions sincerely. They will give it as the human soul by simply doing good deeds and hoping for the pleasure and reward of Allah Subbahanahu Wa ta'ala.

Third. The meaning of capital is that Worship, it is a belief in spiritual values that underlie faith and devotion for each member of the batobo group to their God. They will carry and do the job as well as involves God in himself, his heart and mind. The purpose of our life as human in this world is to worship. The batobo group believes that whatever they do in this world they will be responsible hereafter.

However, when we try to explore further the meaning of the existing capital in the traditional batobo event, there are some that are still of materialistic value. There are some people who judge it as measured by a material (money). That is what brings changes and differences the current situation today. Furthermore all of it should be back to the attitude and personality of each individual. Due to the human nature is not perfect, everything is influenced by lust and lust. In fact perfection belongs only to Allah Subbahanahu Wa ta'ala and we will go hereafter.

\section{References}

Ahmed, E. A. (1994). Accounting Postulates and Principles from an Islamic Persfektive. Review of Islamic Economics, 1, Vol. 3, No. 2, pp. 1-18.

Alfindo, R. (2016). Perubahan Budaya Batobo pada Era Modernisasi di Desa Simandolak Kecamatan Benai Kabupaten Kuantan Singingi. Jurnal Fisip. Vol. 1 Februari, page 1-14

Bertens, K.(1987). Filsafat Barat dalam abad XX. Indoensia; Gramedia

Bourdiue,P.(1983). The of Capital.(T.A. Nice,Ed) Originally Published as Okonomisches Kapital, Kulturelles Kapital, soziales Kapital in soziale ungleicbbeiten (Soziale Welt, Sonderbelft.2), pp.183-98

Hamidy, UU.(2003).Jagad Melayu Dalam Lintasan Budaya Di Riau. Indoenesia:Bilik Kreatif Press

Hines, R.D (1998). Financial In Accounting: in Communicating, Reality, We Construct Reality. Ccounting Organization and Society Vol.13, No.3, pp. 251-261

Husserl, E.(1970). The Crisis of European Sciences and Phenomenolog and Introduction to phenomenological Philoshopy Trans. David Carr. Evanston:Northwestern University Press.

Is, Kamaliah, dan Gusnardi. (2014). Pengaruh Modal Fisik, Modal Finansial, dan Modal Intelektual Terhadap Kinerja Perusahaan (Studi Kasus pada Perusahaan Food and Beverages yang terdaftar di BEI tahun 2009-2013). Jurnal Ekonomi Vol.22, no.3 September 2014

Jenkins,R.(2004). Membaca Pikiran Pierre Bourdieu. Yogyakarta:Kreasi Wacana

Kamus Besar Bahasa Indonesia (KBBI). (1988). Badan Pengembangan dan Pmebinaan Bahasa. Balai Pustaka.

Kamayanti, A. (2016). Metodologi Penelitian Kuaitatif Akuntansi: Pengantar Regiositas Keilmuan. Jakarta Selatan: Yayasan Rumah Peneleh.

Kuswarno,E.M (2009). Fenomenologi Pedoman dan Contoh Penelitian:Widya Padjajaran.

Koencaraningrat.(1980).Bahasa Melayu Bahasa Nasional dan Bahasa Jawa.Pekanbaru: Pemerintah Provinsi Daerah Tingkat 1 Riau Pekanbaru.

Mahdalena,N. (2016). Nilai Kearifan Lokal Subak sebagai Modal Sosial Tranmigrasi Etnis Bali. Jurnal Akuntansi Multiparadigma. Vol.7, No.2, pp. 171-188. http://dx.doi.org/10.18202/jamal.2016.08.7015

Mahar,C., Richard,H., \& Chris,W.(2009). Posisi Teoritis Dasar (Habitus x Modal) + Ranah = Praktik.Yogyakarta:Jalasutra.

Mulawarman, A.D.(2010). Integrasi Paradigma Akuntansi:Refleksi atas Pendekatan Sosiologi Dalam Ilmu Akuntansi.Jurnal Akuntansi Multiparadigma Vol.1 No.1, pp. 155-171. http://dx.doi.org/10.18202/jamal.2010.04.7086

Morgan,G.(1988). Accounting As Reality Construction: Towards a New Epistemology For Accounting Practice. Accounting Organizations and Society, Vol.13. No.5, pp. 477-485

Moustakas, Clark,Phenomenologycal Reseach Method.(1994). Sage Publication Inc.USA. 
Nelson,J.(2009).Psychology.Religion and Spirituality.New Yowk:Spinger Science Bussiness media.

Oxford.(1989).The Oxford English Dictionary.University Press.

Pernyataan Standar Akuntansi Keuangan. (2007) (PSAK 21). Akuntansi Ekuitas

Pernyataan Standar Akuntansi Keuangan. (2007) (PSAK 45). Pelaporan Keuangan Organisasi Nirlaba

Sariubang,M.,Qomariyah,R., dan Kristianto,L.2014. Peranan Ternak Kerbau dalam Masyarakat Adat Toraja di Sulawesi Selatan.JITV,Vol.19 no.2. Seminar Nasional Teknologi Peternakan dan Veteriner 2010.

Seligman,M.(2005). Authentic Happunes:Menciptakan Kebahagiaan dengan Psikologi Positif (Terjemahan).Bandung:Mizan Pustaka

Sudarma,M.(2010). Paradigma Penelitian Akuntansi dan Keuangan.Jurnal Akuntansi Multiparadigma,Vol.61.No.1, pp. 97-108. http://dx.doi.org/10.18202/jamal.2010.04.7082

Tumirin \& Abdurrahim,A.(2015).Makna Biaya Dalam Upacara Rambu Solo.Jurnal Akuntansi Multiparadigma,Vol.6.No.2. hlm 175184. http://dx.doi.org/10.18202/jamal.2015.08.6014

Triyuwono, Iwan.(2006). Persfektif Metodologi dan Teori Akuntansi Syariah Jakarta: PT.Raja Grafindo Persada.

Triyuwono, Iwan.(2006b).Persfektif Metodologi dan Teori Akuntansi Syariah. Jakarta: PT.Raja Grafindo Persada.

Triyuwono, Iwan. (2012).Akuntansi Syariah:Persfektif Metodologi dan Teori (3 ed). Jakarta: Raja Grafindo Persada.

Triyuwono, Iwan. Mulawarman.A.D., Dzamhuri, A., dan Darsono,P., (2016) Filsafat Ilmu Akuntansi. Jakarta: Mitra Wacana Media.

Publisher's Note: SSBFNET stays neutral with regard to jurisdictional claims in published maps and institutional affiliations.

\section{(c) (1)}

(C) 2021 by the authors. Licensee SSBFNET, Istanbul, Turkey. This article is an open access article distributed under the terms and conditions of the Creative Commons Attribution (CC BY) license (http://creativecommons.org/licenses/by/4.0/).

International Journal of Research in Business and Social Science (2147-4478) by SSBFNET is licensed under a Creative Commons Attribution 4.0 International License. 